\title{
A new genus of Phengodidae (Coleoptera) from the Neotropical Region
}

\author{
Viridiana Vega-Badillo ${ }^{1,3}$; Santiago Zaragoza-Caballero ${ }^{1,4}$ \& Michael A. Ivie ${ }^{2}$
}

\author{
${ }^{1}$ Universidad Nacional Autónoma de México (UNAM), Posgrado en Ciencias Biológicas. CdMx, Mexico. \\ ${ }^{2}$ Montana State University (MSU), Montana Entomology Collection (MTEC). Bozeman, MT, United States. \\ ORCID: http://orcid.org/0000-0003-0996-2946. E-mail: mivie@montana.edu \\ 3 ORCID: http://orcid.org/0000-0001-7064-6040. E-mail: viridiana.vega@st.ib.unam.mx \\ ${ }^{4}$ ORCID: http://orcid.org/0000-0002-0235-318X.E-mail: zaragoza@ib.unam.mx
}

\begin{abstract}
Cleicosta, a new genus of Phengodidae containing two new species, C. equatoreana sp. nov., and C. monaguense sp. nov., are described. Additionally, a new combination for Cenophengus breviplumatus Wittmer, 1976 is included. Cleicosta gen. nov., is the thirty-eighth genus assigned to the beetle family Phengodidae in the new world and is also the most morphologically similar to Cenophengus LeConte, 1881. Both genera exhibit clearly separated tentorial pits, vertical frons and simple tarsomeres. In Cleicosta gen. nov., however, the antennal rami are 1.5 times longer than the corresponding antennomere, the pronotum is subquadrate and the elytra are short, reaching the first or second abdominal segment. In addition, it presents an aedeagus with lateral lobes slender, parallel exteriorly, narrowed medially to toothless apex.
\end{abstract}

Key-Words. Diversity; Taxonomy; Cleicosta; Elateroidea.

\section{INTRODUCTION}

The coleopteran family Phengodidae LeConte, 1861 comprises 37 genera and 282 species in Americas. It has traditionally been classified into three subfamilies: Phengodinae LeConte, 1861; Mastinocerinae LeConte, 1881; and Penicillophorinae Paulus, 1975 (Constantin, 2014; Zaragoza-Caballero \& Pérez-Hernández, 2014; Roza et al., 2017, 2019; Vega-Badillo \& ZaragozaCaballero, 2019; Roza \& Mermudes, 2019, 2020). These subfamilies are present in the New World, from southern Canada to the north of Chile and Argentina (Costa \& Zaragoza-Caballero, 2010). Recently, Kundrata et al. (2019) by phylogenetic analysis, considered Cydistinae Paulus, 1972, to be part of the Phengodidae. Cydistinae consists of two genera distributed in Asia Minor: Cydistus Bourgeois, 1885 which includes six species, and Microcydistus Kundrata et al., 2019 with one species. The collection records for this family are limited to local sites, and their low vagility suggests that its species present high levels of endemism (Roza et al., 2017). Thus, several characteristics of the phengodid species could be related to their geographical boundaries (Viviani \& Bechara, 1997). The aim of this study is to increase our knowledge of the family Phengodidae by describing a new genus based on two new species and transferring one previously described species into this genus.

\section{MATERIAL AND METHODS}

We examined specimens deposited at MTEC (Montana Entomology Collection "From Ivie Michael Ivie Collection", Bozeman Montana, U.S.A.), plus the holotype of Cenophengus breviplumatus Wittmer, 1976, deposited at NMNH (National Museum of Natural History, Smithsonian Institution, Washington D.C., U.S.A.) (Floyd Schockley, curator). All specimens are pinned. By means of a Zeiss Discovery V8 stereoscopic microscope equipped with a $1 \times$ lens and a $1.6 \times$ eyepiece, the following measurements were taken: body length, interantennal and interocular distance, length and width of head, pronotum, elytra, scape, antennomeres, antennal rami, maxillary and labial palps, and tarsomeres. Holotype measurements are expressed in millimeters. The aedeagus was extracted from six specimens, and a wing was detached from three; these were glued onto cardboard triangles and pinned under corresponding specimens. Photographs were taken with a Zeiss Axio Zoom V16 microscope equipped with a Plan NeoFluar Z 1×10.25 FWD 56 lens. Lastly, the aedeagi of the new species were examined by means of the Hitachi SU1015 SEM microscope at the Laboratorio de Microscopía y Fotografía de la Biodiversidad, Instituto de Biología, UNAM. General terminology follows Lawrence et al. (2011), except for membranous wing veins, that
Pap. Avulsos Zool., 2020; v.60.special-issue: e202060(s.i.).06 http://doi.org/10.11606/1807-0205/2020.60.special-issue.06 http://www.revistas.usp.br/paz http://www.scielo.br/paz

Edited by: Sônia A. Casari / Gabriel Biffi

Received: 27/09/2019

Accepted: 14/01/2020

Published: 04/03/2020
ISSN On-Line: 1807-0205

ISSN Printed: 0031-1049

ISNI: 0000-0004-0384-1825

http://zoobank.org/1544DC3E-0933-469E-ACAE-4D587BABDB4E 
was taken from Kukalová-Peck \& Lawrence (1993). Labels of the type specimens are arranged in sequence from top to bottom, where the data for each label are within double quotes (" "), a slash (/) separates the rows, and information between brackets ([ ]) provide the correct information for label mistakes.

Depositories: The specimens are deposited in, National Museum of Natural History, Smithsonian Institution, Washington D.C., U.S.A. (NMNH), the Colección Nacional de Insectos (CNIN) of the Universidad Nacional Autónoma de México (UNAM) and the Museo del Instituto de Zoología Agrícola Francisco Fernández Yépez (MIZA) of the Universidad Central de Venezuela (UCV).

\section{RESULTS}

A key, only for the mastinocerine genera exhibiting distinctly separated tentorial pits, is provided, adapted from Zaragoza-Caballero \& Pérez-Hernández (2014) with modifications in couplet $2^{\prime}$.

2. Labial palpi 2-segmented; tarsomeres simple ......................................... 3

2. Labial palpi 3-segmented; first tarsomeres of pro- and/or mesothoracic legs with ventral 'comb' of bristle-like setae.

3. Elytra long; last 3 tergites exposed; gular sutures divergent anteriorly; lateral lobes of aedeagus parallel, with apical teeth .....

Cenophengus LeConte

3. Elytra short, last 7 tergites exposed; gular sutures parallel anteriorly; lateral lobes of aedeagus narrowed medially to toothless apex............

..Cleicosta gen. nov.

4. Fifth and sixth sternites with apical crescent-shaped area containing transverse line of dense setae; first tarsomere of pro- and mesothoracic legs with complete 'comb'. Distremocephalus Wittmer

4. Fifth and sixth sternites without crescent-shaped area; first tarsomere of prothoracic legs with complete ventral 'comb'.

Mastinowittmerus Zaragoza

\section{Cleicosta gen. nov.}

Type species: Cenophengus breviplumatus Wittmer, 1976.

Diagnosis: Cleicosta gen. nov., is morphologically similar to Cenophengus LeConte, 1881: both genera exhibit clearly separated tentorial pits, vertical frons and simple tarsomeres. Cleicosta gen. nov., differs from Cenophengus in the arrangement of the gular sutures: parallel anteriorly in the new genus and divergent anteriorly in Cenophengus. Additionally, in Cleicosta gen. nov., pronotum is subquadrate in shape and elytra are short (reaching only first or second abdominal segment). In Cenophengus the pronotum is rectangular, and elytra long, last 3 tergites exposed. Other important characteristics in Cleicosta gen. nov., are: aedeagus with lateral lobes parallel, elongate, narrowed medially to toothless apex; in Cenophengus with lateral lobes parallel, with apical teeth.
Head: Wider than long (Fig. 1A), fully exposed; integument smooth, glossy, coarsely punctuate: antennae 12-articulated serrated, extending slightly beyond pronotal posterior margin; antennomeres $4^{\text {th }}$ to $11^{\text {th }}$ with lanceolate rami, 1.5 to twice times longer than respective antennomere; frons vertically produced; interantennal distance nearly equal to first antennomere length; eyes finely facetted, hemispherical, variable in length; labrum 3 times wider than long; mandibles simple, thin, falcate; maxillary palpi 4-segmented; terminal palpomere bullet-shaped with apex acute, longer than preceding $3 ; 3^{\text {rd }}$ palpomere shorter than $2^{\text {nd; }}$ labial palpi 2-segmented; terminal palpomere fusiform, 5 times longer than preceding one; tentorium with 2 distinctly separated pits; gular sutures parallel anteriorly (Fig. 1B).

Thorax: Pronotum subquadrate (Fig. 1C); anterior angles rounded, posterior angles acute, lateral margins rounded; integument smooth, glossy, densely punctured (Fig. 1D); prosternal anterior margin almost straight; sternal suture complete. Elytra short, reaching $1^{\text {st }}$ or $2^{\text {nd }} a b-$ dominal segment, 3 to 4 times longer than wide, subparallel, apex rounded. Posterior wings with posterior medium vein $(M P 1+2)$ always present; posterior radial vein (RP) absent; radial cell open; venation otherwise variable. Length of legs gradually increasing from pro- to metathoracic legs; tarsi simple; in all pairs of legs, length of $4^{\text {th }}$ tarsomere equal to half the length of $5^{\text {th }}$; claws simple.

Abdomen: Integument shiny, punctured, densely setose; penultimate sternite with posterior margin sinuate; last sternite deeply notched. Aedeagus with median lobe cylindrical, with apex rounded; lateral lobes elongate, parallel externally, narrowed medially to toothless apex (Figs. 1E-G).

Etymology: The new genus is named Cleicosta in recognition of the outstanding work of Dr. Cleide Costa, on her eightieth birthday. Her first name was abbreviated as "Clei" in order to avoid homonymy with the elaterid genus Cleidecosta Johnson, 2002. Gender feminine.

\section{Cleicosta breviplumata (Wittmer, 1976) comb. nov.} (Figs. 2A-D)

\section{Cenophengus breviplumatus Wittmer, 1976: 450.}

Type material: Holotype (o" NMNH): "Monserrate/ Bogota/ Colombia/ 10,000/ ALT 03.V.46/ E.A.Chapin" "Cenophengus breviplumatus/ det. W. Wittmer" "Type No./ 73885/ USNM"“Loan from/ USNMNH/ 2081909”.

Diagnosis: Cleicosta breviplumata comb. nov., is similar to $C$. monaguense sp. nov., but they differ in their interantennal and interocular distances. In C. breviplumata comb. nov., the interantennal distance equals the width of the antennal fossa, whereas in C. monaguense sp. nov., it is greater. The interocular distance is four times greater than eye width in C. breviplumata comb. nov.; in C. mona- 
guense sp. nov., it is three times greater. Additionally, in C. breviplumata comb. nov., the first and second tarsomeres are equal in length in all three pairs of legs, whereas in C. monaguense sp. nov., the first tarsomere is shorter than the second in all legs.
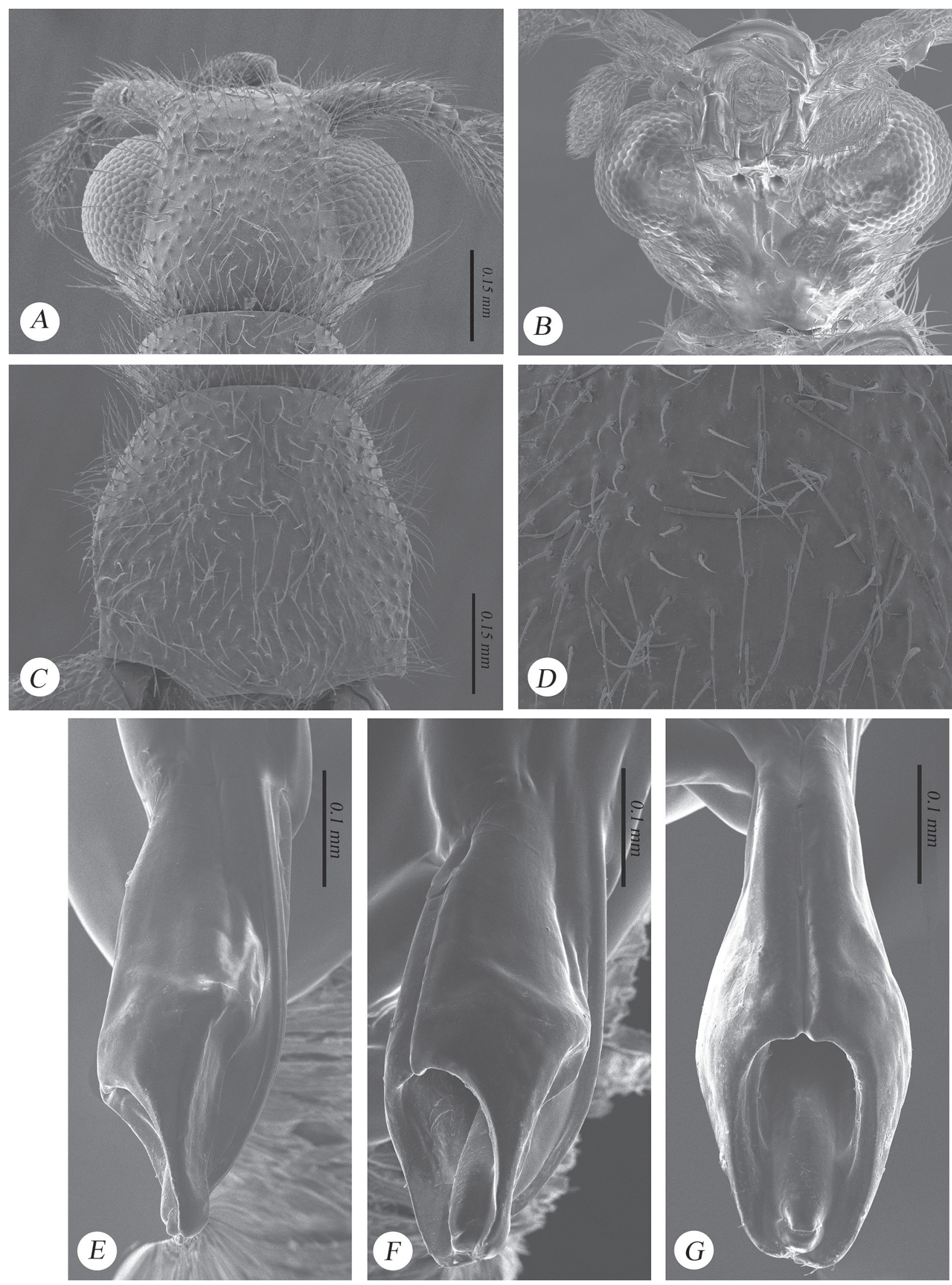

Figure 1. Cleicosta monaguense sp. nov., SEM images: (A) head dorsal; (B) head ventral; (C, D) pronotum. Aedeagus: (E) dorsal; (F) lateral; (G) ventral. 
smooth, coarsely punctuate, each puncture bearing a brown seta; interantennal distance (0.12) equal to antennal fossa width (0.11); eyes small, hemispherical, finely facetted, not prominent, longer (0.2) than wide (0.08); interocular distance (0.33) 4 times greater than eye width; antennae short (1.63), barely reaching pronotal posteri- or margin; $1^{\text {st }}$ antennomere $(0.15)$ as long as $2^{\text {nd }}$ and $3^{\text {rd }}$ combined; $3^{\text {rd }}$ cup-shaped and short $(0.05), 4^{\text {th }}$ in length $0.12,5^{\text {th }}$ to $10^{\text {th }}$ about equal in length $(0.16) ; 11^{\text {th }} 0.1$ in length; $12^{\text {th }}$ (terminal) bullet-shaped with apex acute (0.15); antennal rami lanceolate, 1.5 times longer than respective antennomere; labrum bilobed; terminal max-
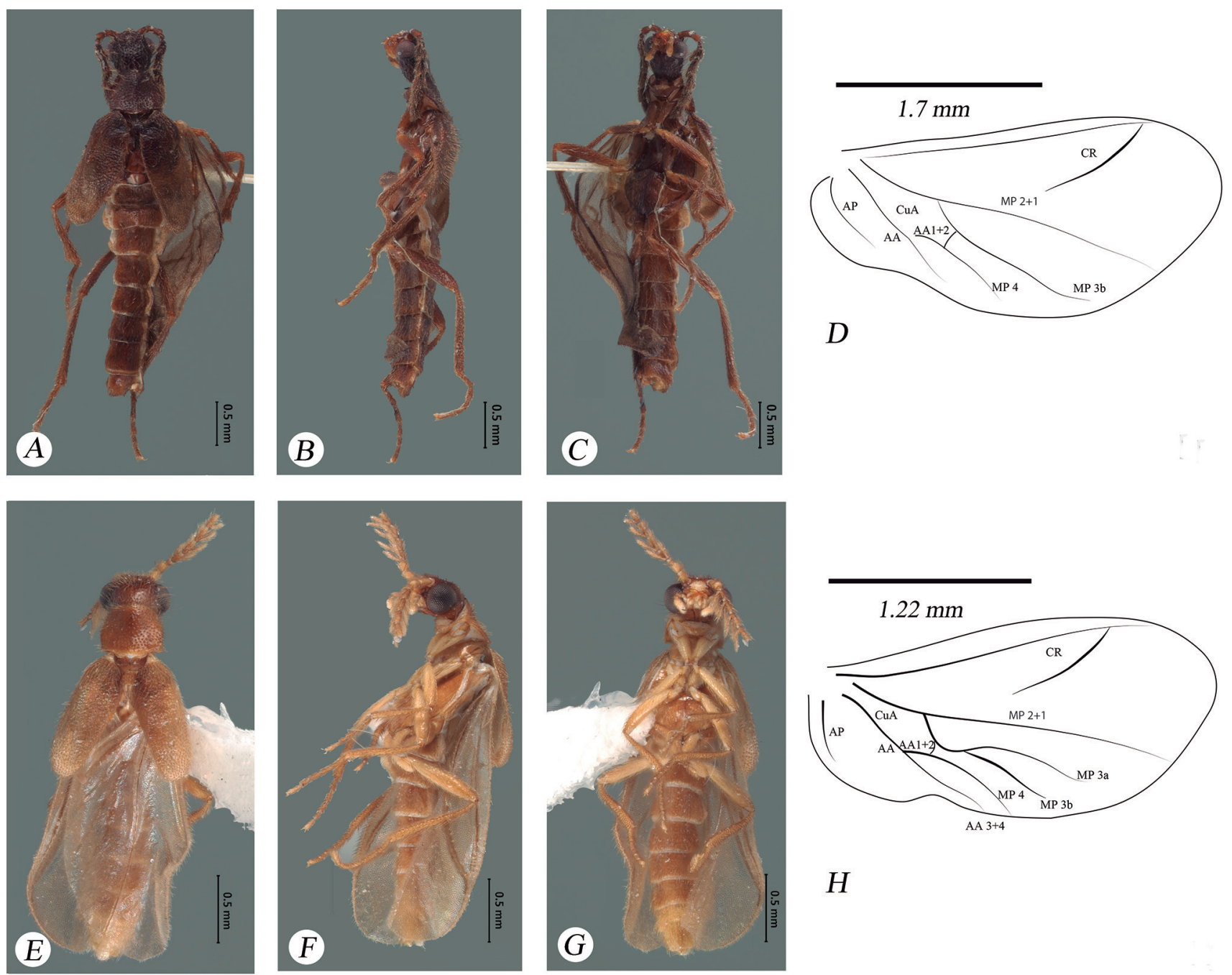

\section{$H$}
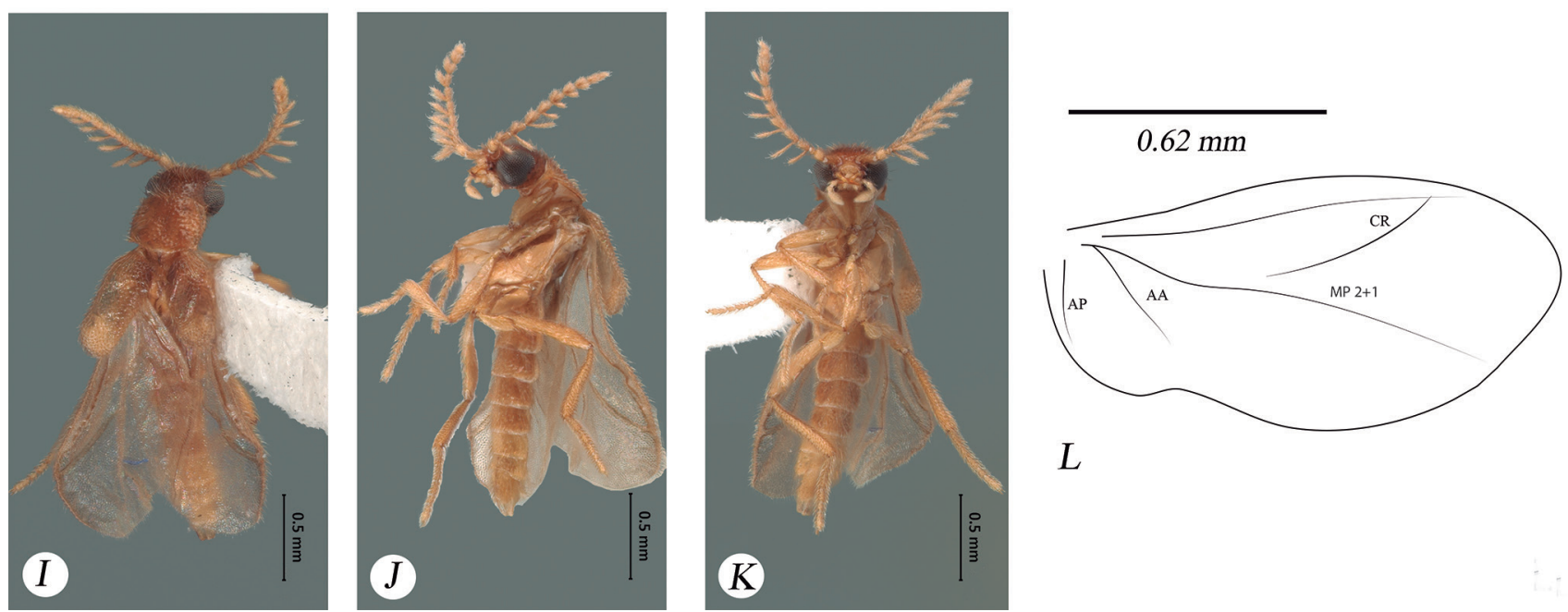

$L$

Figure 2. Cleicosta breviplumata comb. nov., habitus: (A) dorsal; (B) lateral; (C) ventral; (D) posterior wings. Cleicosta monaguense sp. nov., habitus: (E) dorsal; (F) lateral; (G) ventral; (H) posterior wing. Cleicosta equatoreana sp. nov., habitus: (I) dorsal; (J) lateral; (K) ventral; (L) posterior wing. Venation: posterior medium vein (MP $1+2$ ), posterior radial vein (RP), radial cell (CR); posterior anal vein (AP), anterior anal vein (AA) divided into AA $1+2$ and $A A 3+4$, the cubital-anal vein (CuA) and MP 4, MP 3a, MP 3b posterior veins. 
illary palpomere robust, spindle-shaped (0.12), longer than preceding 3 combined; terminal labial palpomere spindle-shaped (0.05), 5 times longer than preceding one.

Thorax: Pronotum wider (0.49) than long (0.45); integument smooth, coarsely punctuate; each puncture bearing a brown seta; disc convex, anterior margin almost straight, anterior angles rounded, lateral margins convergent anteriorly, posterior margin rounded, posterior angles acute; scutellum spatulate, with small notch on posterior margin; integument shiny, densely punctured; each puncture bearing a brown seta; elytra short, 3.5 times longer (1.3) than wide (0.37); posterior wings (Fig. 2D) with posterior medium vein (MP $1+2$ ) distinct, posterior radial vein (RP) absent, radial cell (CR) open; cubital-anal area of wings with posterior anal vein (AP) distinct, anterior anal vein (AA) incomplete and distinct, cubital-anal vein (CuA) distinct, mid-posterior veins MP 4 and MP $3 b$ present; $1^{\text {st }}$ and $2^{\text {nd }}$ tarsomeres of pro-, meso- and metathoracic legs about equal in length.

Abdomen: Integument shiny, punctured, with silky appearance due to dense setosity; penultimate sternite with posterior margin emarginate; last sternite with posterior margin deeply notched; pygidium with posterior margin emarginate; aedeagus slender.

\section{Females and immatures: Unknown.}

Distribution: Bogota, Colombia (Fig. 3).

\section{Cleicosta monaguense sp. nov. (Figs. 2E-H)}

Type material: Holotype ( $\sigma^{\star}$ MIZA): "VENEZUELA: Monagus [Monagas], $700 \mathrm{~m} /$ Caripe, Cueva \#87-82/ Guacharo, 20-30 July 1987/ Forest over coffee/ S \& J Peck, Malaise FIT" "From the Michael Ivie Collection". Paratypes: "VENEZ: Monagus, 700 m/ Caripe, Cueva \#87-82/ Guacharo, 20-30 July 87/ Forest over coffee/ S \& J Peck, Malaise" "Michael Ivie Collection" (30' CNIN, 30 MTEC).

Diagnosis: Cleicosta monaguense sp. nov., can be separated from the similar C. breviplumata comb. nov., by its greater interantennal distance which equals twice the antennal fossa width (interantennal distance equals antennal fossa width in C. breviplumata comb. nov.). The interocular distance is three times greater than eye width in C. monaguense sp. nov., and in C. breviplumata comb. nov., it is four times greater. Additionally, in C. monaguense sp. nov., the first tarsomere is shorter than the second in all legs, whereas in C. breviplumata comb. nov., the first and second tarsomeres are equal in length in all three pairs of legs.

Description: Male: Body length 3.50, maximum body width 0.46 . Light brown body.
Head: Surface concave, wider (0.53) than long (0.41); at eye level, wider (0.53) than pronotum (0.46); integument smooth thick and roughly dotted densely and coarsely punctuate, each puncture bearing a brown seta, interantennal distance (0.12) equal to twice antennal fossa width (0.07); eyes large, hemispherical, finely facetted, prominent, longer $(0.22)$ than wide $(0.01)$; interocular distance (0.31) 3 times greater than eye width; antennae short (1.17), barely reaching pronotal posterior margin, $1^{\text {st }}$ antennomere $(0.10)$ longer than next 2 combined, $3^{\text {rd }}$ cup-shaped and short $(0.03), 4^{\text {th }}$ in length $0.10,5^{\text {th }}$ to $10^{\text {th }}$ about equal in length $(0.11), 11^{\text {th }}$ measuring $0.09,12^{\text {th }}$ (terminal) bullet-shaped with apex acute (0.12); antennal rami lanceolate, 1.5 times as long as respective antennomere; labrum bilobed; terminal maxillary palpomere robust, spindle-shaped, as long as preceding 3 combined (0.15); terminal labial palpomere spindle-shaped (0.07), 6 times as long as preceding one.

Thorax: Pronotum wider (0.46) than long (0.42), integument smooth, densely and coarsely punctuate; each puncture bearing a brown seta; disc convex, anterior margin almost straight, anterior angles rounded, lateral margins slightly curved, posterior margin curved, posterior angles acute; scutellum spatulate, with small notch on posterior margin, integument shiny, densely punctuate, each puncture bearing a yellow seta; elytra short, 2.5 times longer (0.95) than wide (0.33); posterior wings (Fig. $2 \mathrm{H}$ ) with posterior medium vein (MP $1+2$ ) long and distinct, posterior radial vein (RP) absent, radial cell (CR) open; wing cubital-anal area with anterior anal vein (AA) (divided into AA $1+2$ and AA $3+4$ ) and posterior anal

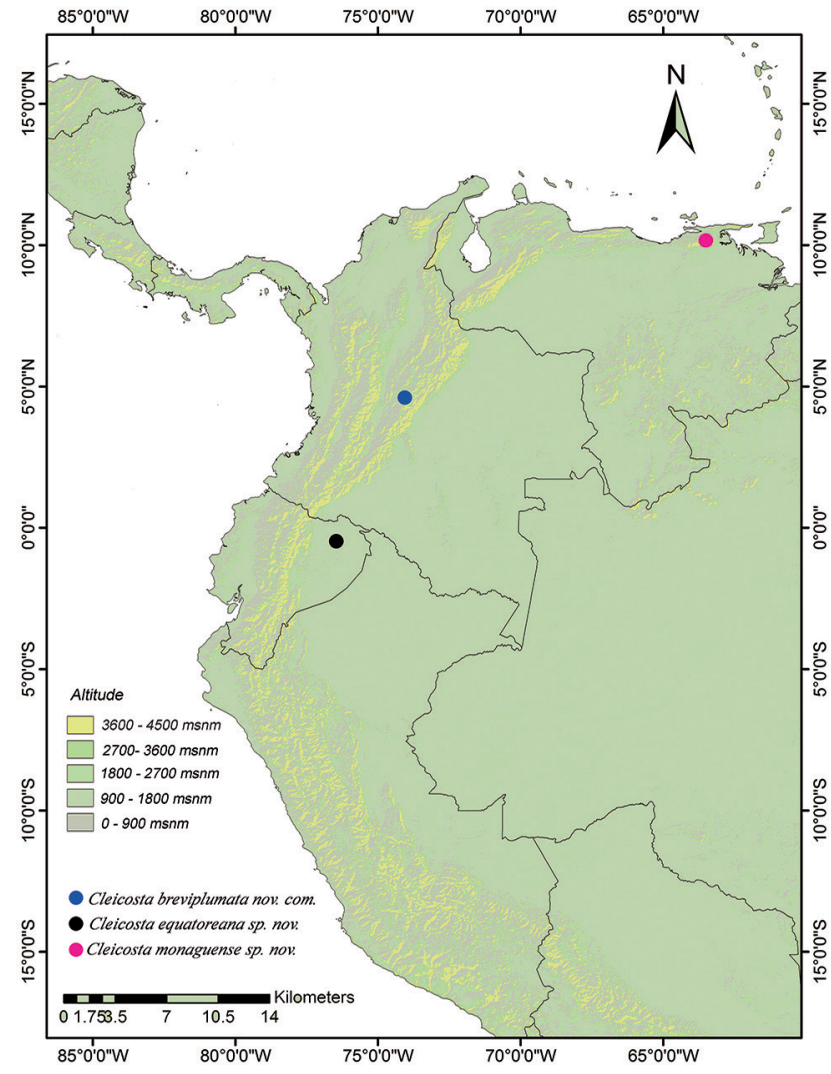

Figure 3. Geographical distribution of Cleicosta gen. nov., species. 
vein (AP) distinct, cubital-anal vein (CuA) divided into MP 4, MP 3a and MP 3b mid-posterior veins; $1^{\text {st }}$ tarsomere of all legs shorter than $2^{\text {nd }}$.

Abdomen: Integument shiny, punctuate, with silky appearance due to dense setosity; penultimate sternite with posterior margin sinuate, last sternite with posterior margin notched; pygidial posterior margin straight.

Female and immatures: Unknown.

Distribution: Monagas, Venezuela (Fig. 3).

Etymology: Specific epithet alludes to the type locality.

\section{Cleicosta equatoreana sp. nov. (Figs. 2I-L)}

Type material: Holotype ( $\left.\sigma^{\circ} \mathrm{NMNH}\right)$ : "ECUADOR: Sucumbios/ Sacha Lodge, $270 \mathrm{~m} / 00.5^{\circ} \mathrm{S}, 76.5^{\circ} \mathrm{W} / 04-14$ May 1994/ P. Hibbs, Malaise"“Michael Ivie Collection”.

Diagnosis: Cleicosta equatoreana sp. nov., is similar to C. monaguense sp. nov., however they differ in their interantennal distance. In C. equatoriana sp. nov., it is equal to antennal fossa width; in C. monaguense sp. nov., interantennal distance is greater than fossa width. Additionally, in C. equatoreana sp. nov., the terminal maxillary palpomere is 1.5 times longer than the preceding three combined, whereas in C. monaguense sp. nov., the terminal palpomere is equal in length as the preceding three combined.

Description: Male: Body length 2.4, maximum width 0.38 . Body color light brown.

Head: Surface concave; wider (0.42) than long (0.32); at eye level, wider (0.42) than pronotum; integument smooth, coarsely punctuate, each puncture bearing an amber seta; interantennal distance (0.06) equal to antennal fossa width (0.07); eyes large, hemispherical, finely facetted, prominent, longer (0.18) than wide (0.08); interocular distance $(0.24) 3$ times greater than eye width; antennae short (0.81), barely reaching pronotal posterior border; $1^{\text {st }}$ antennomere longer $(0.1)$ than next 2 combined, $3^{\text {rd }}$ cup-shaped, small $(0.03), 4^{\text {th }} 0.07$ in length, $5^{\text {th }}$ to $10^{\text {th }}$ about equal in length $(0.08), 11^{\text {th }} 0.06$ in length, $12^{\text {th }}$ (terminal) bullet-shaped with apex acute (0.06); antennal rami lanceolate, twice as long as respective antennomere; labrum bilobed; terminal maxillary palpomere robust, spindle-shaped (0.12), 1.5 times longer than preceding 3 combined; terminal labial palpomere spindle-shaped (0.04), 4 times longer than preceding one.

Thorax: Pronotum wider (0.38) than long (0.31); integument smooth, coarsely punctuate, each puncture bearing an amber seta; disc convex, anterior margin almost straight, posterior margin convex with small notch; scutellum spatulate, posterior margin with small notch on posterior margin, integument shiny, densely punctuate, each puncture bearing an amber seta; elytra short, 3 times longer (1.02) than wide (0.32); posterior wings (Fig. 2L) with posterior medium vein (MP $1+2$ ) distinct, posterior radial vein (RP) absent, radial cell (CR) open; cubital-anal wing area with undivided anterior anal vein (AA) and posterior anal vein (AP) visible; $1^{\text {st }}$ and $2^{\text {nd }}$ tarsomeres of all legs about equal in length.

Abdomen: Integument shiny, punctuate, with silky appearance due to dense setosity; penultimate sternite with posterior margin emarginate.

Female and immatures: Unknown.

Distribution: Sucumbios, Ecuador (Fig. 3).

Etymology: Specific epithet alludes to the type locality.

\section{Key to species of Cleicosta gen. nov.}

1. Body length $2.4 \mathrm{~mm} ; 4^{\text {th }}$ (terminal) maxillary palpomere 1.5 times longer than preceding 3 combined; antennal rami lanceolate, twice as long as respective antennomere .............Cleicosta equatoreana sp. nov.

1. Body length greater than $3 \mathrm{~mm} ; 4^{\text {th }}$ (terminal) maxillary palpomere as long as preceding 3 combined; antennal rami lanceolate, 1.5 times longer than respective antennomere.

2. Body color light brown; interocular distance 3 times greater than eye width; $1^{\text {st }}$ tarsomere of all legs shorter than respective $2^{\text {nd }}$ tarsomere.. .Cleicosta monaguense sp. nov.

2. Body color brown; interocular distance 4 times greater than eye width; $1^{\text {st }}$ and $2^{\text {nd }}$ tarsomeres of all legs about same length Cleicosta breviplumata comb. nov.

\section{ACKNOWLEDGMENTS}

We would like to thank to Edgar Uriel Garduño Montes de Oca and Martín Zurita García for their review and comments that enriched this work. We thank Susana Guzmán Gómez and Berenit Mendoza Garfias for technical assistance in taking the photographs. The first author thanks the Graduate program in Biological Sciences, UNAM.

\section{REFERENCES}

Constantin, R. 2014. Contribution à la connaissance des Phengodidae de Guyane et description de huit espèces nouvelles (Coleoptera, Elateroidea). Coléoptères de Guyane.. Le Coléoptériste (Supplément), 8: 86-104.

Costa, C. \& Zaragoza-Caballero, S. 2010. Phengodidae LeConte, 1861. In: Leschen, R.A.B.; Beutel, R.G. \& Lawrence, J.F. (Eds.). Coleoptera, Beetles. Vol. 2: Morphology and systematics (Elateroidea, Bostrichiformia, Cucujiformia partim). Berlin, Walter de Gruyter. p. 126-135. (Handbook of Zoology, Arthropoda: Insecta)

Kukalová-Peck, J. \& Lawrence, J.F. 1993. Evolution of the hind wing in Coleoptera. The Canadian Entomologist, 125: 181-258. 
Kundrata, R.; Blank, S.M.; Prosvirov, A.S.; Sormova, E.; Gimmel, M.L.; Vondráček, D. \& Kramp, K. 2019. One less mystery in Coleoptera systematics: the position of Cydistinae (Elateriformia incertae sedis) resolved by multigene phylogenetic analysis. Zoological Journal of the Linnean Society, 187(4): 1259-1277. DOI

Lawrence, J.F.;Ślipiński, A.; Seago, A.E.; Thayer, M.K.; Newton, A.F. \& Marvaldi, A.E. 2011. Phylogeny of the Coleoptera based on morphological characters of adults and larvae. Annales Zoologici, Warszawa, 61: 1-21.

Roza, A.S. \& Mermudes, J.R.M. 2019. New genus and two new species of railroadworm Beetles from Brazil, with a discussion on asymmetry of aedeagus in the family (Coleoptera: Phengodidae). Annales Zoologici, Warszawa, 69: 805-816. DO

Roza, A.S. \& Mermudes, J.R.M. 2020. A new genus of railroad-worm beetles from the Atlantic Rainforest from Brazil (Coleoptera: Phengodidae, Mastinocerinae). Papéis Avulsos de Zoologia, 60(Special Issue): 1-12, e202060(s.i.).10. DOI

Roza, A.S.; Mermudes, J.R.M. \& Silveira, L.F.L. 2019. New species and rediagnosis of Akamboja, and a new record for A. minimum (Coleoptera: Phengodidae, Mastinocerinae). Journal of Natural History, 52: 2935-2947.
Roza, A.S.; Quintino, H.Y.S; Mermudes, J.R.M. \& Silveira, L.F.L. 2017. Akamboja gen. nov., a new genus of railroad-worm beetle endemic to the Atlantic Rainforest, with five new species (Coleoptera: Phengodidae, Mastinocerinae). Zootaxa, 4306: 501-523.

Vega-Badillo, V. \& Zaragoza-Caballero, S. 2019. Nueva especie del género Phengodes (Phengodella) (Coleoptera: Phengodidae) y una clave para los fengódidos de Belice. Revista Mexicana de Biodiversidad, 90: e902863.

Viviani, V.R. \& Bechara, E.J.H. 1997. Bioluminescence and Biological Aspects of Brazilian Railroad-Worms (Coleoptera: Phengodidae). Annals of the Entomological Society of America, 90: 389-398.

Wittmer, W. 1976. Arbeiten zu einer Revision der Familie Phengodidae (Coleoptera). Entomologische Arbeiten aus dem Museum G. Frey, 27: 415-524.

Zaragoza-Caballero, S. \& Pérez-Hernández, C.X. 2014. Sinopsis de la familia Phengodidae (Coleoptera): trenecitos, bigotudos, glow-worms, railroadworms o besouros trem de ferro. México, D.F., Universidad Nacional Autónoma de México. 128p. 